\title{
Transatlantica
}

Revue d'études américaines. American Studies Journal

\section{From Uncle Tom to Nat Turner: An Overview of Slavery in American Film, 1903-2016}

\section{Melvyn Stokes}

\section{(2) OpenEdition}

\section{Journals}

Electronic version

URL: https://journals.openedition.org/transatlantica/12814

DOI: 10.4000/transatlantica.12814

ISSN: $1765-2766$

\section{Publisher}

Association française d'Etudes Américaines (AFEA)

Electronic reference

Melvyn Stokes, "From Uncle Tom to Nat Turner: An Overview of Slavery in American Film, 1903-2016", Transatlantica [Online], 1 | 2018, Online since 18 September 2019, connection on 01 February 2023. URL: http://journals.openedition.org/transatlantica/12814 ; DOl: https://doi.org/10.4000/ transatlantica.12814

This text was automatically generated on 1 February 2023.

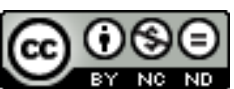

Creative Commons - Attribution-NonCommercial-NoDerivatives 4.0 International - CC BY-NC-ND 4.0 https://creativecommons.org/licenses/by-nc-nd/4.0/ 


\title{
From Uncle Tom to Nat Turner: An Overview of Slavery in American Film, 1903-2016
}

\author{
Melvyn Stokes
}

1 When Steven Spielberg released Amistad (1997), his film about the long legal battle to free the black African slaves found aboard a Spanish ship in 1839, reviewer Christopher Hemblade commented that "as slave epics go, and let's be honest, there ain't much demand for them, this is about the most visceral and unclichéd version you could hope for" (Hemblade). In spite of Hemblade's praise, Amistad's history at the box office seemingly justified his more general claim: that there was little popular American demand for movies about slavery. Nevertheless, in the second decade of the twentyfirst century, a number of films appeared that seemed to defy this observation by both dealing with slavery and being commercially as well as critically successful: Spielberg's account in Lincoln (2012) of how the sixteenth president led the campaign to pass the Thirteenth Amendment abolishing slavery through the House of Representatives; Quentin Tarantino's Django Unchained (2012), dealing with a former slave trying to free his wife from captivity; and Steve McQueen's 12 Years a Slave (2013), retelling the story of real-life Northern free black Solomon Northup's life as a slave and eventual escape from slavery after he has been kidnapped and sold. In January 2016, yet another film about slavery, directed by and starring Nate Parker, previewed at the Sundance Film Festival. This article will explore the ways in which these recent films have represented the institution of African slavery in America and contrast and contextualize them-and their reception-with earlier American films dealing with the same subject. ${ }^{1}$

Early American cinema was quick to make a film about slavery. But that film was located within a dense network of literary and theatrical reference points. In 1903, Edwin S. Porter directed Uncle Tom's Cabin for the Edison Company. The film had only fourteen shots. It was probably comprehensible only to those who knew the story it told (Staiger 105). But that included a very large section of the American population. Harriet Beecher Stowe's classic antislavery novel Uncle Tom's Cabin, first published in 
1852, was still in 1899 the book most frequently borrowed from the New York Public Library. Many Americans were also familiar with the story through pirated adaptations of the book for the stage: by the 1890s there were around five hundred traveling theatrical companies in the United States putting on what had become known as "Tom Trouper" or "Tommer" shows and a 1902 observer estimated that one in every thirtyfive Americans would see the play that year (Staiger 105, 108). There would be at least six more film versions of the story by 1927, most focusing on the different fortunes and cruel fate of Tom himself, the brutality of slave owner Simon Legree, and the escape of Eliza and her child to free territory.

3 A very small number of early films also focused on black resistance to the cruelty of slave owners. The Slave Hunt, a Vitagraph movie from 1907, showed a planter whipping a slave woman. A young man, probably her son, rescues her by killing the planter. $\mathrm{He}$ flees, pursued by bloodhounds, but is eventually captured and killed. This emphasis on interracial violence went way beyond the treatment of slavery in Stowe's novel, offending the Variety film critic who saw it as "not at all refined or agreeable" and leaving "a bad taste" (Variety Film Reviews, 1983a). In the following year, a film called The Slave's Vengeance had a slave whipped at the stake on his master's orders. In revenge, he kidnaps his master's young daughter and runs away. When he is caught, the young girl improbably pleads for his life. A reviewer praised this "pathetic finish" to what had been "a stirring if not happily chosen subject" (Variety Film Reviews, 1983a).

What is most obvious, looking back, is not the number of early films following in the wake of the antislavery movement and focusing on the evils of slavery. It is the conjunction between the beginnings of American cinema and the growth of a very different view of slavery. This had its roots in four principal intellectual and cultural changes. The first was the development of the myth of the "Lost Cause," created by Southern writers in the decades after the ending of the Civil War to justify why they had fought. These writers-William Alexander Carruthers, John Esten Cooke, Mary Johnston, John Pendleton Kennedy, Sarah Pryor, and, most crucially, Thomas Nelson Page-romanticized what they presented as the "Old South" of antebellum days in mass-circulation magazines with their mainly Northern readership. According to the "Lost Cause," slavery was not the main reason for the Civil War. The slaves themselves had been happy and thoroughly content with their status-and, it was argued, the South itself would eventually have abolished slavery on its own initiative (Blight 10; Connelly and Bellows 1-38). The second change was the emergence of history as a professional academic discipline. Scholars who wrote about slavery-notably Georgiaborn and educated Ulrich B. Phillips-in the main represented it as a benign and largely benevolent institution that had helped "civilize" African Americans (Smith and Inscoe). The third change was the increasing tendency-growing from multiple intellectual routes, including ideas of Aryanism, Anglo-Saxonism, Social Darwinism, and other pseudo-sciences of the late nineteenth and early twentieth centuries-to rank races in a hierarchy with whites at the top and blacks near the bottom (Baker 11-98; Tucker 9-137). Finally, there was the emergence in the early twentieth century of the "Civil War" genre as a popular category of feature films. The first movies of this type were made in the North, addressed to Northern audiences, and presented a view of the war biased towards the North. Beginning in 1909, however, filmmakers discovered that what Eileen Bowser called "the more romantic, noble, and heroic ideals to be found in the defeated South" were popular also in Northern cities (Bowser 178). From 1911, films reflecting the Southern point of view-including at times flattering perceptions of its 
"peculiar institution" of slavery-were twice as numerous as films with a Northern bias (Bowser 177-179; Ehrlich 77).

5 All these trends reached their apogee in D.W. Griffith's epic film, The Birth of a Nation, in 1915. The first part of the film balances the kindness and generosity of spirit of the owner of the Cameron plantation in South Carolina with the loyalty and joie de vivre of his well-treated slaves. Dr. Cameron (Spottiswoode Aitken), the head of the family, is introduced in an intertitle as "the kindly master of Cameron Hall." The main sequence involving slavery shows the Camerons and their Northern guests visiting the slave quarters. An intertitle informs viewers that the slaves are enjoying their "two-hour interval given for dinner, out of their working day from six to six." The implicit idea that slaves were not overworked was developed even further when enslaved men are shown having the energy to put on an impromptu dance to entertain their white visitors. Under slavery, Griffith's film suggests, whites and blacks get on well together because each knows their place. In the second part of the film, with slavery gone, such racial harmony is lost and black men in particular slough off the "civilized" ways they have learned from whites in order to revert to the primitivism of their forebears.

Almost half a century ago, in a collective analysis of John Ford's movie Young Mr. Lincoln, the editors of Cahiers du cinéma argued that even film texts that seemed most overtly to represent the ideology of a ruling class could sometimes be "subversive," in the sense that they contained inherent cracks and contradictions that invited oppositional readings ("Young Mr. Lincoln"). This is certainly true of the portrayal of slavery in The Birth of a Nation. The fact that slavery was a system of forced labor in which humans were traded simply as chattels is underlined in the very first sequence of the film in which manacled slaves are shown being auctioned in a town square. But the really revealing moment comes in the second part of the film, when Dr. Cameron is brought in chains to face his former slaves. The old master is taunted and even physically assaulted by an African American woman (Madame Sul Te-Wan). This second part of the film is about miscegenation-supposedly the threat posed by black men to white women. What the hostility shown to Dr. Cameron in this sequence seems to underline is that the reality of miscegenation had been white slave owners, as well as their sons and overseers, using their power to prey sexually on black female slaves.

7 Although a new, long version of Uncle Tom's Cabin by Harry A. Pollard was released in $1927,{ }^{2}$ there were comparatively few Hollywood films about slavery made until the end of the 1920s. In part, this was because of the baleful influence of The Birth of a Nation. The controversy surrounding the release of Griffith's film discouraged the production of movies on similar themes. The Birth of a Nation even narrowed the range of black characters shown in American films in general and its influence led to the movie industry itself banning the showing of miscegenation on screen, first in the "Don'ts and Be Carefuls" of 1927 and later in the Production Code of $1930 .{ }^{3}$ What few films did refer to slavery during this period mainly treated it as benign. The subsequent period of true nostalgia for the old South and slavery was the consequence of two things, one technological (the arrival of sound films), the other economic and social (the advent of the Great Depression).

8 The introduction of sound from 1927 made it possible to incorporate features of what was thought of-rightly or wrongly-as "black" music into film. Movies such as Hearts in Dixie (1929) and Hallelujah! (1929), even though-as Jack Temple Kirby points out-these 
two films were actually set after the Civil War (Kirby 68), seemed to suggest that African Americans had carried on living freely on plantations even after emancipation. "Ringing with banjos and brimming with high-kicking, happy darky stereotypes," Kirby writes, "the[se] films conveyed an interpretation of slavery basically the same as Thomas Nelson Page's" (Kirby 67). Other films in what might be seen as a "plantation musical" genre included Dixiana (1930), Mississippi (1935), Swanee River (1939), Way Down South (1939), Dixie (1943), and Song of the South (1946). Perhaps the most popular of all these movies were the Shirley Temple "Southerns," such as The Little Colonel and The Littlest Rebel, both from 1936.

9 The economic depression that began in 1929 also encouraged interest in the lost world of the Southern plantation. Hard times and high industrial unemployment made the supposed stability and seemingly timeless rural way of life in the antebellum South appear especially appealing. To those suffering economic instability or threatened by unemployment in cities, the romantic myth of the old South was a highly seductive one. "Audiences could marvel," observed Edward D.C. Campbell, Jr., "at a culture so reliant on the land and the seasons rather than on the city and business trends" (Campbell 76). As the 1930s wore on, the plantations themselves became grander: Hollywood's representation of the way of life of the old South became a complex negotiation between filmmakers' desires and ambitions, previous productions, and what spectators now had been led to accept. The relatively small and intimate plantations in Carolina (1934) and So Red the Rose (1935) made way for the far more impressive Halcyon plantation of Jezebel (1938) and, of course, Tara and Twelve Oaks in Gone with the Wind (1939).

Consistently, however, whether plantation musicals or plantation melodramas, these films depicted happy slaves loyally supporting their masters and mistresses. The one film of this kind that, at least to some degree, may seem to contradict this portrayal was So Red the Rose. Unusually, this showed plantation blacks-told that freedom is about to be achieved-who stop working for their master and family and, encouraged by their leader Cato (Clarence Muse), start to seize the livestock of their owners. But this "slave revolt" is easily put down by the daughter of the plantation family (Margaret Sullavan) who confronts Cato and reduces him to silence by evoking memories of the strong interracial bonds that had (supposedly) existed under slavery. Ultimately, therefore, this brief moment of black agency fails to undermine Hollywood's trope of slavery as intrinsically a benign institution.

11 Although it was not the last plantation melodrama, Gone with the Wind was in many ways the most successful in commercial-and perhaps cultural-terms. ${ }^{4}$ It offers many benign images of slavery. It is the black foreman, Big Sam (Everett Brown), who-in an unlikely assertion of racial autonomy-calls "quittin' time" in the cotton fields of Tara. Mammie (Hattie McDaniel), although a slave, is clearly a considerable social presence in the O'Hara household. Pork (Oscar Polk) has been close enough to Gerald O'Hara (Thomas Mitchell) to inherit his former master's watch. House slaves are allowed or made (it is unclear which) to attend evening prayers at Tara. Ashley (Leslie Howard) later insists that slaves had not been treated as badly as the white convicts Scarlett (Vivien Leigh) proposes to hire, and talks nostalgically of "the high soft negro laughter from the [slave] quarters" that could be heard in the plantation house in "[t]he warm still country twilight." Scarlett herself, confronted with Big Sam and other field hands cheerfully going off "to dig trenches for the Confederacy"-willing participants in their 
own continuing enslavement-, recognizes each of the workers by name. When they are hurried on their way by a Confederate officer, she calls after them-in a perfect expression of the supposed benign character of slavery-to let her know if they are "sick or ill." Shortly before his death, Gerald o'Hara underlines to Scarlett the mixture of sternness and benevolence that had-at least according to "Lost Cause" writersbeen used to control the slaves: "You must be firm with inferiors, but you must be gentle with them, especially darkies."

Birth of a Nation, however, Gone with the Wind also has sequences that challenge the view of slaves as happy, contented, and faithful. At such moments, slavery is revealed as a brutal system of labor exploitation. The shot of small boys hanging on the bell that is ringing out the end of the working day at Tara has a certain joyousness to it, but is also a reminder of the reality of child labor. This is underlined even more emphatically by the young black girls who are fanning the sleeping white girls on the afternoon of the barbecue at Twelve Oaks. Resting on the assumption that whites could not work in the heat, while blacks were used to it, the stereotype is nonetheless challenged by a close-up of one little black girl tiredly stroking her hair. Scarlett's treatment of Prissy (Butterfly McQueen) is particularly revealing. Prissy is the only slave we see actually subjected to physical violence-Scarlett slaps her face. Scarlett also threatens Prissy in two other ways. She promises to "whip the hide off" her if she upsets Melanie while sitting with her and-in one of the most revealing phrases in the whole film-threatens to "sell her South." This tapped into the tendency for slave owners to sell difficult, recalcitrant, or runaway slaves to the chain gangs in the frontier parts of states such as Mississippi, where work was much more arduous and the survival rates much lower than in the coastal plantations of Georgia and the Carolinas. Part of the worst effects of such sales was that they reflected the ultimate reality of slavery: that slaves were property rather than people. The slave concerned was also punished by being separated, probably for good, from his or her family: we know that Prissy has family since she tells Rhett (Clark Gable) that her mother would punish her ("wear me out with a corn stalk") for entering Belle Watling (Ona Munson)'s saloon/brothel. ${ }^{5}$ There is one other oblique reference in Gone with the Wind to selling slaves. Uneasy at the attempt to raise money by allowing the men at a charitable ball to bid for their preferred dance partner, Dolly Merriwether (Jane Darwell) asks the doctor's wife Mrs. Meade (Leona Roberts): "How can you permit your husband to conduct this [...] slave auction?"

13 A few of the plantation films of the 1930s and 1940s had a long afterlife. Disney's Song of the South, described by Jack Kirby as "the ultimate expression of plantation harmony after the [Shirley] Temple movies," continued to be shown in some movie theatres until the mid-1970s (Kirby 70). Gone with the Wind has periodically been re-released and, after its first showing on American network television-watched by 110 million people-in 1976, became a staple of mass television entertainment (Campbell 188; Taylor 2). But, in the years after the Second World War, two mainstream American films displayed considerably more ambivalence over the institution of slavery. The Foxes of Harrow (1947), loosely based on a bestselling novel by black writer Frank Yerby, undercut the perception of slavery as benign by showing a slave woman who would prefer to die rather than have her child brought up in slavery. Ten years later, Band of Angels, the film version of Robert Penn Warren's 1955 novel, had Clark Gable playing Hamish Bond, a former slave trader ashamed of his earlier occupation. 

Butler in Gone with the Wind, yet the institution of slavery in Band of Angels was depicted as much harsher than in the earlier film. Band of Angels, observed the New York Times critic, featured "brutal slave-traders [...] the heroine cowers on the slave-block piteously [...] and bloodhounds chase slaves across fields" (Crowther). By 1957, with the civil rights movement starting to take off, Hollywood was beginning to revisit the more critical view of slavery that had its roots in the nineteenth-century abolitionist tradition. Biberman, a member of the "Hollywood Ten," the group of communist or excommunist Hollywood employees who had unsuccessfully confronted the House UnAmerican Activities Committee in 1947 and served time in prison for contempt of Congress. In a major rewrite of the "benign" view of slavery, Biberman's film showed it as a system of exploitation that eventually drove slaves themselves to revolt. The film focused on the story of a black Christian slave, Luke (Ossie Davis), who is sold by his Kentucky master to save his few remaining slaves. He passes into the hands of MacKay (Stephen Boyd), a brutal Mississippi planter. MacKay's mistress is a black woman, Cassy (Dionne Warwick). Luke and Cassy plan to escape together, but the plan fails and Lukerather than accepting MacKay's offer of freedom in exchange for betraying other blacks -dies fighting. The film-in some ways like Stowe's Uncle Tom's Cabin-despite being highly critical of slavery, was curiously balanced in places. As the reviewer for Variety noted, "[s]ympathetic slave owners are shown as well as hard driving profiteers [...] some white men cared for keeping [black] families together while others-usually because of economic gain-chose to break [up] the family unit and actually breed slaves" (Variety Film Reviews, 1983b).

Biberman's Slaves failed completely at the box office. Its only audience of reasonable size was African American residents of big cities. As long as films covering slavery did so within the context of the nostalgia for the Old South, it was possible to make films that appealed to the dominant white audience in the United States. When old South films were no longer produced-in large part because of the shift in racial attitudes as a result of the growing effectiveness of the civil rights movement in the late 1950s and 1960s-it was harder and harder to see how slavery could be featured in a commercially successful film. Director Franklin J. Schaffner did so with Planet of the Apes in 1968 by discussing the issue obliquely and metaphorically. In this science fiction film, the planet in another galaxy 2,000 years in the future is ruled by apes with humans as their oppressed slaves (Crémieux 232-237).

During the 1970s, two films enjoyed mixed success by developing further the theme of miscegenation as defined by the Production Code of 1930. In 1957, Kyle Onstott published a novel called Mandingo about a slave-breeding plantation in Alabama. Five years later, he published a second novel, Drum, intended as a sequel to the first (Kirby 116). Italian producer Dino De Laurentiis thought the books provided him with the opportunity to break further into the American movie market. Mandingo, released as a film in 1975, blended-because of its portrayal of a sexually hyperactive black man, played by boxer Ken Norton-with the "blaxploitation" genre of the time. ${ }^{6}$ New York Times critic Vincent Canby commented that Mandingo offered "steamily melodramatic nonsense" that conveyed no impression of "what life on the old plantation was really like" because of its "erotic interest in the techniques of humiliation, mostly with sex 
and violence" (Canby, 1975). Other reviewers were equally caustic: according to one, Mandingo was an "embarrassing and crude film" that wallowed "in every cliché" associated with "the slave-based [...] pre-Civil War South" (Variety Film Reviews, 1983c).

18 Clearly designed as an "exploitation" film, Mandingo reached a large audience mainly for its prurience in dealing with the theme of miscegenation, with two pairs of interracial lovers and a brutal ending. In spite of its many faults, Mandingo did focus on the sexual politics of slavery, undercutting earlier perceptions of it as a benign institution. Robin Wood, in fact, would later-controversially-describe it as "the greatest Hollywood film about race" (Wood 267) for its highly critical view of Southern white patriarchy. (The idea of "Mandingo" boxing, of course, would later be taken up by Quentin Tarantino in Django Unchained.) Its sequel, Drum, failed to repeat the financial success of Mandingo at the box office, though its treatment of slavery was just as brutal. In the end, the New York Times reviewer dismissed it as "exploitation junk." "Life on the old plantation was horrendous," he admitted, "but movies like this are less interested in information than titillation, which, in turn, reflects contemporary obsessions more than historical truth" (Canby, 1976).

The career of the civil rights movement-with its emphasis on the long and continuing tradition of racial discrimination-made it difficult, perhaps even impossible, to return to the nostalgic view of the old South with its happy, contented slaves. Moreover, beginning principally in the 1970s, there was a growing move on the part of historians to document the active role played by slaves in their own liberation. The Freedmen and Southern Society project, beginning in 1976, played a major part in this process (see, for example, Berlin, 1998; Berlin, 2003). In 1990, according to Kate Masur, Ken Burns's documentary series for PBS on the Civil War began, at least to some extent, to disseminate the results of this scholarship to a wider public. But, as Masur points out, one of Hollywood's latest films to deal with the issue of slavery-Steven Spielberg's Lincoln, released in 2012-turns the clock back "even if inadvertently, [with] the outdated assumption that white men are the primary movers of history and main force of social progress" (Masur).

Spielberg's film focuses on the three-week period in January 1865 during which Lincoln (Daniel Day-Lewis) masterminded the successful attempt to get the Thirteenth Amendment to the Constitution abolishing slavery through the House of Representatives. While we see black Union soldiers in several shots in the movie, the only slaves shown are those in Alexander Gardner's photographs. In order to focus on Lincoln as a shrewd politician fighting a winning battle in a bitterly divided House of Representatives, Spielberg's Lincoln ignored the fact, as Eric Foner argues, that slavery "died on the ground, not just in the White House and the House of Representatives." Escaped slaves since the beginning of the war had made the fate of slavery a national issue and, by the time of the House debate, former slaves were already "sacking plantation homes and seizing land" (Foner, 2012).

21 The year after the Freedmen and Southern Society project was founded in 1976, the American Broadcasting Corporation first screened (January 1977) an eight-part TV miniseries adapted from Alex Haley's novel Roots, telling the story of a black family's struggle to survive over several generations. Amongst other things, it showed the experience of the Middle Passage (the transportation by sea of countless Africans to the Americas), a shipboard slave rebellion, and the sexual exploitation of enslaved women. The program-makers made a range of compromises to make Roots palatable to a mainly 
white television audience. They added many new white characters, emphasized the theme of racial integration and-rather paradoxically-sold the idea that it was a universal human story of survival and liberation rather than a study of black/white relations. But, with a total audience of 130 million Americans, it suggested there might be a possible audience for the right film about slavery (Graham 184). Hollywood filmmakers, however, remained unconvinced. It took two decades for one of the industry's most significant players to commit to making what he hoped would be a major movie about slavery. Released in 1997, Amistad was Steven Spielberg's attemptas he himself put it-to do "for the American experience of slavery what Schindler's List did for the Holocaust" (quoted in Jeffrey 77). Sadly, from his point of view, Spielberg was about to be disappointed.

The film focused on the experiences of a group of black Africans who, in 1839, revolted against and largely slaughtered the crew of a Spanish boat, the Amistad, that was carrying them into slavery. Stopped by the American navy off the coast of Connecticut, they were the subject of three trials to decide whether they were free or not. The lawyer arguing the last case was former president, now congressman, John Quincy Adams (Rediker). Actress Debbie Allen had first come across a fictionalized account of the real-life Amistad affair in 1978 and tried for many years to produce a movie about it. Her luck apparently changed when she met Spielberg and persuaded him it would be a great subject for a film. Around this time, Spielberg and his wife adopted two African American children: there were probably personal as well as commercial reasons for his decision (Jeffrey 79-80). The film followed the increasing tendency of historians to give agency to slaves: it dealt with the aftermath of a revolt by kidnapped Africans to win back their own freedom. Its central character, and leader of the revolt, is Cinqué, played by Djimon Hounsou from Benin. Cinque also learns to participate in the judicial proceedings that ultimately secure freedom for himself and his companions. The film, indeed, ultimately suggests that the American legal system, if left free of political interference, will in the end come up with the correct moral verdict. But, sixteen years after the Supreme Court freed the Amistad Africans on a technicality (rather than the broader case for their liberty made in the film), Chief Justice Roger B. Taney announced the verdict in the Dred Scott case of 1857, which decided that African American slaves were only property, with no civil rights.

Perhaps the major problem with Amistad was that the story it told involved Africans rather than African Americans. It used African rather than American actors in black roles, had them speak an accurate version of the Mende language in what is now Sierra Leone (the area from which the Amistad captives came), and at the end of the film has most of them, including Cinqué, sailing back home to Africa. Yet Amistad made little deeper attempt to explore African cultures: as Nigel Morris notes, the captives wear a variety of tribal costumes and there are shots of Muslim Africans praying but these are "neither foregrounded nor framed centrally" (Morris 256). What the movie did show, more revealingly than any of its predecessors, was the process by which Africans were captured and transported to become slaves in the New World. The Middle Passage sequence in Amistad is probably the most honest-and most brutal-treatment of Africans on a slave ship up to that point in American cinema. ${ }^{7}$ It showed the terrible conditions on the slave ships, the chains and poor food, the vicious punishments, the high mortality rate, and also the exploitation of slave women by white sailors (the shot of dancing to music). Most graphically of all, it shows the throwing overboard of fifty slaves when the white crew realizes they do not have enough provisions to feed 
everyone aboard. These sequences proved the most relevant of all to African American spectators, forcing them to confront the background to their own history. For many, it was an acutely distressing experience. "Only a masochist," observed Warrington Hudlin, president of the Black Filmmakers foundation, "would want to spend two hours watching themselves be degraded and dehumanized" (quoted in Jeffrey 88). At an early showing of the film, an African American woman became hysterical during the Middle Passage sequence and rushed out of the theatre. "I felt like I was on the ship," she later explained, "and it was too much. I just really couldn't take it anymore" (quoted in Jeffrey 88). Making Cinque the principal character of the narrative, of course, may also have made the movie's failure more likely with the majority white audience, reducing the film's white characters to three main categories: the ridiculous (the Christians shown praying and singing); the unscrupulous and ineffective, like abolitionist Lewis Tappan (Stellan Skarsgård) and President Martin van Buren (Nigel Hawthorne); and those, like cynical lawyer Roger Baldwin (Matthew McConaughey) and the elderly John Quincy Adams (Anthony Hopkins), who are ennobled through Cinqué's influence.

Although Amistad was not a complete box office failure, it had a gross worldwide of only around $\$ 60,375,000$ on an estimated production budget of $\$ 36,000,000 .^{8}$ Its example may have discouraged other directors from working on other projects dealing with slavery. It is very noticeable that when Spielberg himself made the successful Lincoln fifteen years later, the film-as noted above-deals with slavery only as a political issue and shows no slaves. But, within a year of the release of Lincoln in the United States in November 2012, two other films were released with slavery itself at their center. Both were considerable box office successes. Quentin Tarantino's Django Unchained returned a worldwide gross of $\$ 425,368,000$ on an estimated production cost of $\$ 100$ million. Steve McQueen's 12 Years a Slave returned a worldwide gross of $\$ 178,414,000$ on an estimated production cost of only $\$ 20,000,000$. Did the success of these two films suggest that both directors and audiences were now ready to engage with the realities of African American slavery? For different reasons connected with the two films, I suspect not.

Django Unchained, as might be expected of Tarantino, is a mélange of genres: spaghetti western, buddy movie, exploitation flick, blaxploitation film, a revenge/rescue melodrama, a movie about a quest. Adilifu Nama, moreover, writes that "in the long run and overall" it "is a Gothic horror film" fusing together "terror with laughter" (Nama 109, 117-118). But it is also, for much of its length, a "Southern" or plantation film with a lineage going back at least to The Birth of a Nation. It has its own Southern lady (Laura Cayouette), who stands up for (white) Southern manners in the way Ellen O'Hara had once done. It has its own "faithful soul," Stephen (Samuel L. Jackson), this time an "Uncle Tom" figure of surprising malevolence. The plantation itself-much of the film was shot at the Evergreen Plantation in Louisiana'-still visually seduces filmmakers, even Tarantino. Yet underpinning Django Unchained is a sustained deconstruction of the myths of the earlier benign plantation genre. It echoes the work of antebellum abolitionists in emphasizing "the horrible cruelties daily inflicted on the bodies of slave women and men" (Kaster 76). On Calvin Candie (Leonardo DiCaprio)'s plantation in Mississippi, called "Candieland" with deceptive sweetness, brutalities include attack dogs killing a runaway slave, "mandingo" fighters wrestling with each other to the death, and the hot airless box on the lawn in which Django's wife Broomhilda (Kerry Washington) is being punished for attempting (again) to escape. 

takes for a castrated black man to bleed to death. For much of the film, former slave Django is very much the junior partner to bounty hunter Dr. King Schultz (Christoph Waltz), who teaches him how to kill and, in return for some months' assistance, promises to aid him in looking for his wife. It is only after Schultz kills Candie, triggering his own death, that Django becomes the lead character. By virtue of three massacres, Django-now armed to the teeth and toting stylish, anachronistic sunglasses -wins freedom for himself and Broomhilda (though, as the glamorous black couple ride away from burning Candieland, it is hard not to wonder how they will evade Mississippi slave patrols). With its traditional cinematic clichés and stereotypes of plantation life, and its cathartic if imaginary violence, Django Unchained is a modern fantasy of what could have happened rather than what did. It does not inspire remorse for the existence of slavery so much as an illusory sense of redemption for two fictional former slaves. To Reynaldo Anderson, D.L. Stephenson, and Chante Anderson, Tarantino's film could not "function as a liberating text in any meaningful way. It can only entertain the global masses through fiction and fraud" (Anderson et al. 240). different. Based on a real story, the kidnapping of black Northern freeman Solomon Northup in 1841, his exploitation in the slave South, and final freedom in 1853, the film is based on Northup's own 1853 memoir of his experience. It was favorably received by most critics. Tomris Laffly, contrasting it with Tarantino's "gruesome revenge fantasy," greeted it as "the most unforgiving account of slavery to date" (Laffly 132-134). Douglas Kellner believed that McQueen had "undeniably produced one of the most compelling indictments of slavery in contemporary cinema" (Kellner 23). To Ann Hornaday it was "the defining epic so many have longed for to examine-if not cauterize-America's primal wound" (quoted in Garrett). Calum Marsh praised McQueen for his persistence in showing so much of the day-to-day brutality of slavery: the director intended, he wrote, "to show the reality of slavery not by fleeting suggestion, but by a campaign to exhaust and overwhelm" (Marsh).

In contrast, a small number of writers criticized McQueen's film for the unrelieved harshness of his portrayal of slavery. Armond White argued that "[b]rutality, violence and misery get confused with history in 12 Years a Slave." White dismissed the film as belonging "to the torture porn genre" but complained that "it is being sold (and mistaken) as part of the recent spate of movies that pretend 'a conversation about race"' (White). In a more subtle critique of the film, Julian Carrington pointed out the number of points at which the film invented things (the murderous crewman rapist on the riverboat) or distorted Northup's own account (while conceding Mistress Epps was of a jealous disposition, he also observed that "there was much in her character to admire") to create the impression "that slavery was practiced strictly by some wicked, Southern-bred subspecies of humanity." The main problem with this approach, Carrington argued, was that

[b]y characterizing Northup's oppressors as semi-demonic sadists, McQueen and [screenwriter John] Ridley invite viewers to overlook the reality of American slavery as a system of economic exploitation that was practiced not by some intrinsically malevolent historical "other," but by individuals not fundamentally dissimilar to themselves, and which remains evident in contemporary systemic disparities of power and privilege. (Carrington 75) ${ }^{10}$ 
In fact, there are a number of things 12 Years a Slave gets right in historical terms. Slave labor was especially hard in the cotton and sugar plantations of the Deep South: the film's depiction of Louisiana slaves roused by a bugle at dawn to work and the weighing of the cotton picked at the end of the day is much truer than the idyllic sequence in Gone with the Wind with Big Sam calling "quittin' time." The advice to Northup from another black "not to tell anyone you can read and write if you want to survive" relates to the fact that most Southern states by the 1840 s made it illegal for slaves to be taught to read and write. Slaves were bought and sold as property, which at times involved breaking up families-or even the sale of natural mulatto children of slave owners, like Eliza (Adepero Oduye) in the film. Epps (Michael Fassbender)'s reading the Bible to his slaves emphasizes that, from the 1830s, many proslavery writers insisted slavery was justified in the Bible, both in the practices of Hebrews in the old Testament and the later words of St. Paul (Snay 53-109; Irons 133-246). The film shows in a number of sequences-including the unexplained lynching party Northup blunders upon on his way to town-how easy it was for white men to kill blacks with no real possibility of legal consequences. In one sequence, moreover, it indicates that there was racial prejudice in the North as well as the South: the New York shopkeeper we see fawning over the wealthy-looking Northup reacts only with suspicion to the badly dressed African American who also wanders into his shop.

As a film, 12 Years a Slave also includes a number of elements that are less convincing. The many times during the film in which slaves sing-including "Roll, Jordan, Roll" after the death of "Uncle Abe" (Dwight Henry)-imports a cliché from other movies since the plantation musicals of the early sound era. Epps's malevolent wife (Sarah Paulson) seems to have stepped straight out of Mandingo with her insistence on whipping the life from her husband's black mistress, Patsey (Lupita Nyong'o). The whipping sequence itself, a staple of most films about slavery, is prolonged to the point it seems inspired by McQueen's previous film about sexual fantasies, Shame (2011). The sequences involving miscegenation, notably Epps's sexual exploitation of Patsey, also hark back to Mandingo and Drum. (Having said that, there is also an interesting sequence in which a mulatto woman [Alfre Woodward], clearly married to a white man, invites Northup to tea, suggesting that miscegenation was sometimes acceptable, even formalized.) There are parts of the film that seem far from historically plausible. The liberal carpenter played by Brad Pitt, wandering around the Deep South articulating antislavery views, would have been unlikely in 1853. The aftermath of the sectional compromise of 1850, and the rash of personal liberty laws passed in Northern states in an attempt to negate the effects of the new Fugitive Slave Law, had created a proslavery backlash and growing intolerance in the South (Hamilton 166-190; Potter 121-144). For the same reason, the ease with which Northup's papers as a free man are ultimately accepted and enforced by the local Louisiana sheriff is fairly unconvincing.

McQueen was right to confess in an interview that many people in Hollywood had not wanted his film made. In fact, just as Amistad would never have been made if Spielberg had not become involved, 12 Years a Slave probably would never have been released if it had not been for the support of Brad Pitt and his production company Plan B (Aspden). That the film was shot, released, and went on to win two Oscars is in many ways a remarkable achievement. Yet it peripheralizes African American slavery in two principal ways. In the first place, its hero is a free black from the North. There were a number of kidnappings of free blacks and writing about the experience became 
something of a literary trope in the early 1850 s. But the true story of slavery was not that of the relatively few Northern blacks who were kidnapped or fell foul of the provisions of the Fugitive Slave Law. It was that of the four million who, in the 1850s, lived (and died) under slavery and the small percentage of that number who tried to escape, and the even fewer-some helped by the Underground Railroad-who managed to cross the Mason-Dixon Line into the free states. The manner in which the film was marketed-as an exposure of the kind of slavery that is still prevalent in today's world ${ }^{11}$ -although it underlined the continuing existence of vast social injustices, also helped divert attention from the historical experience of African American slaves in the antebellum South.

Subsequent representations of slavery on film and TV would appear in a different racial and political climate in the United States. Four months before the release of 12 Years a Slave in November 2013, white neighborhood watch volunteer George Zimmerman was found not guilty by a Florida jury of either the murder or manslaughter of black teenager Trayvon Martin, shot in February 2012. Zimmerman's acquittal prompted a national debate surrounding "stand your ground" laws and racial profiling. It also inspired the launch during the summer of 2013 of a new protest organization, Black Lives Matter, which would become nationally visible through the demonstrations it organized in New York City, where African American Eric Garner died on 17 July 2014 after being arrested and restrained by a white police officer, and Ferguson, Missouri, following the shooting of Michael Brown, a black eighteen-year-old, by a white policeman on 9 August 2014. This was only a prelude for what was to come: 2015 saw a record of 1,134 young black men killed by the police-a rate five times higher than that of white men of the same age (Swaine et al.). On 17 June 2015, in a hate crime, white high-school dropout Dylann Roof shot and killed nine black people at Emanuel African Methodist Episcopal Church in Charleston, South Carolina.

By the middle of the second decade of this century, much of the optimism with regard to race relations generated by the election of Barack Obama as the first black President in 2008 had gone. Already, in 2010, the US Bureau of the Census estimated that 38.2 percent of black children under the age of 18 were living in poverty, with the figure for whites at 12.4 percent ("Poverty"). In 2014, according to the Henry J. Kaiser Family Foundation, 26 percent of blacks as a whole lived in poverty, contrasted with 10 percent of whites ("Poverty Rate"). The US Bureau of Labor Statistics reported that unemployment amongst blacks in March 2016 was almost twice as high ( 9 percent) as the general rate of unemployment (5.2 percent) ("Labor Force"). Recent years have also witnessed the undercutting of the Voting Rights Act (1965), one of the principal successes of the civil rights movement, by the Supreme Court in its Shelby County $v$. Holder decision (2013) and the adoption by many states of stricter voter ID laws and other changes to voting rules that have discriminated against black voters (Rutenberg).

There was also growing concern during these years in Hollywood at the lack of racial diversity in the movie industry itself. In response to the nominations for Academy Awards in 2015, April Reign, the managing editor of BroadwayBlack.com, launched the trending hashtag \#OscarsSoWhite, which was revived when the nominations for 2016equally limited in terms of diversity-were announced (P. Ryan). It was against this background that the January 2016 Sundance Film Festival featured a new film by black actor, now also director, Nate Parker. Titled The Birth of a Nation, as a deliberate attempt by Parker to overwrite D.W. Griffith's notorious film of 1915, it dealt with the slave 
rebellion led by Nat Turner in Southampton County, Virginia, in 1831. After the successful screening at Sundance, wrote Amy Taubin, the movie industry and much of the press greeted The Birth of a Nation as the antidote to "Oscars So White." And since the Hollywood establishment had a recent history of preferring slavery narratives to contemporary African American stories (Django Unchained had five nominations in 2013 and won two Oscars; 12 Years a Slave received nine nominations in 2014 and won three), she commented that the new award season might well prove such predictions correct (Taubin 62). Nicole Sperling similarly suggested that there could be a major change towards racial inclusivity at the 2017 Oscars, with The Birth of a Nation leading the charge as "a possible Best Picture contender" (Sperling, 2016b). This was probably much in the mind of Fox Searchlight when they bid a record-breaking $\$ 17.5$ million for the distribution rights (Barnes). Their bid was not the highest one (Netflix reportedly offered $\$ 20$ million) but Parker, intent on a theatrical release to make his film eligible for the Academy Awards, accepted the lower offer. He must also have been aware of Fox Searchlight's reputation "as an Academy Awards powerhouse," having "maneuvered" 12 Years a Slave to the Oscar for best picture in 2014 (Siegel and Ford; Barnes). ${ }^{12}$

Parker's film-like William Styron's 1967 novel-was loosely based on The Confessions of Nat Turner, published by a local white Virginia lawyer, Thomas R. Gray in $1831 .{ }^{13}$ It represents Turner (Nate Parker) as something of a mystic, who dreams of being anointed as a leader and prophet by his African forbears. He is permitted by his owner (the film reduces his several real owners to one) to become literate, but only to strengthen his understanding of the Christian faith. The owner, Samuel Turner (Armie Hammer), then takes him on a tour of neighboring plantations, where he is obliged to preach acceptance of slavery-based on the Scriptures-to other slaves. This tour, an obvious plot device, allows a comparatively innocent Turner the slave to become educated in the true depravities of the slave system, observing overseers with bullwhips, metal collars and face-masks as punishments, vicious dogs, posses of slave catchers and, in one brutal instance, a slave on hunger strike who has his teeth knocked out and is then force-fed (Laws 41; Hulbert 110). This exposure to the gruesome violence and barbarities of the slave system begins to set him on the path towards protest and martyrdom. But it is the grim reality of sexual assault by white men on black women that completes the process.

Sexual violence has been at the heart of several filmmakers' fictional attempts to represent racial relations. In 1915, Griffith's The Birth of a Nation used the alleged threat of rape of white women by black men as his justification for the actions of the Ku Klux Klan. In 1920, black filmmaker Oscar Micheaux demonstrated in Within Our Gates that rape in the South was usually a white man's crime (in Micheaux's movie, a white man is about to assault a mixed-race girl when he realizes she is his daughter). In Parker's The Birth of a Nation, it is the rape of two black women that finally radicalizes Turner and inspires him to lead a slave revolt (Hulbert; Bradshaw). One of them is his wife, Cherry (Aja Naomi King), ${ }^{14}$ who is shown with a heavily battered face that critic A.O. Scott sees as recalling "the open-coffin photographs of Emmett Till, who was lynched for supposedly whistling at a white woman in 1955" (Scott).

In early August 2016, two months before the release of The Birth of a Nation, an episode in Parker's own life threatened to derail completely the notion that his film would be an Oscar contender. In 1999, when Parker was a student at Penn State University, he and his roommate, Jean Celestin (credited as a co-author of the film) had been charged 
with the rape and sexual assault of a young woman. Parker was acquitted but his roommate was found guilty of sexual assault and sentenced to a term in jail. His conviction was overturned on appeal and a new trial granted, but this never took place because other witnesses and the victim were not available. The woman concerned committed suicide in 2012 (Sperling, 2016a; Smith). Reviewers of the new movie could hardly be unaware of this backstory, which as A.O. Scott observed in the New York Times, came "to light at a time when rape on college campuses and the sexual depredations of celebrities are all over the news" (Scott). It led some commentators, including Roxane Gay, to reject the film completely, declaring that she could not "separate the art and the artist" (Gay).

According to the International Movie Database, Parker's The Birth of a Nation cost an estimated $\$ 8,500,000$ to make and had grossed only $\$ 15,858,724$ by 2 December 2016 . The film's meagre return was paralleled by its failure to capture any major awards. Parker had also hoped that his movie would have a powerful political effect: by showing "how deeply the racial injustices and atrocities" represented in the film continued "to reverberate today," it would encourage viewers to become "change agents" (quoted in Barnes). But was it ever likely that a movie based on such a historical episode could have achieved this objective? The slave rebellion led by Nat Turner in tidewater Virginia, in August 1831 is the most famous in US history. Turner and his supporters killed around sixty white men, women, and children on neighboring farms in Southampton County. ${ }^{15}$ After the uprising was suppressed, more than fifty African Americans-including Turner himself-were executed by the state for their part in it and many more, perhaps as many as two hundred, were killed by white mobs and militias (Oates). The story of the Turner rebellion, Justin Chang noted after first viewing the film at Sundance, had a denouement that "will stir deep emotion and inevitable unease" since the film "presents its climactic violence in complicated but unmistakably heroic terms" (Chang).

Most of the principal successes of the civil rights movement of the 1950s and 1960s-in particular the Civil Rights Act (1964) and Voting Rights Act (1965) -came about through non-violence and racial cooperation. It is not easy to see what Parker's film about a man who led a violent revolt against slavery could have brought-as its director hoped -to the current American conversation on race. Certainly, Turner resisted, but his resistance may have actively prolonged the institution he fought. As Lacy K. Ford has pointed out, there was a pronounced historical divide on slavery between the Upper and Lower South (Ford). In 1827, of the 130 abolitionist societies in the entire United States, 106 were in the South, and, according to Donald G. Mathews, "none [of these were] below the southern border of North Carolina" (Mathews 53n42). In the aftermath of the Turner rebellion, Virginia strengthened its black code while many other Southern states passed laws to restrict even further the rights of slaves, including banning them from being taught to read and write. "So many ills of the Negro followed [the revolt]," wrote black scholar John W. Cromwell, himself once a Virginia slave, in 1920, "that one is inclined to question the wisdom of the insurgent leader" (Cromwell 233). The violence of Turner's rebellion helped unify the South in defense of its "peculiar institution." In his own time, Turner's actions were counterproductive. It is hard to see his relevance in battling racial discrimination today.

Between 31 May and 2 June 2016, a four-episode remake of Roots, the 1970s television serial based on Alex Haley's novel, was broadcast on the History, Lifetime, and A\&E TV 
channels. The new series reflected many aspects of changing historical perceptions of slavery since the first series was aired in 1977. It described more accurately the African background to slavery, depicting the economies and cultures of West African kingdoms and showing their involvement in the Atlantic slave trade. The Middle Passage sequences were even more harrowing than in Amistad. The number of white characters was appreciably reduced to strengthen the black storyline. More in tune, as Maureen Ryan noted in Variety, with "new scholarship about the slave trade and the antebellum South," the new Roots foregrounded black agency and slave resistance (M. Ryan). Yet, as Glenn D. Brasher pointed out, most of the resistance shown "is violent, with the enslaved getting retribution in unrealistic fashion and escaping punishment (à la Django Unchained)." In reality, Brasher continued, most slave resistance did not involve the use of force and this focus in Roots "diminishes the accomplishments and courage of the more numerous enslaved individuals who successfully outwitted and successfully manipulated their masters, never letting their slave status define them or destroy their hope and self-esteem" (Brasher).

Despite his criticism, Brasher commented that the new Roots "could stand apart as a movie on its own" and noted that a Blu-ray edition was about to appear (Brasher). The fact, however, that it was first shown only on niche TV channels suggests that-even if made available across several platforms-it is unlikely that it will ever match the audience of 130 million who watched the original series on network TV. This, together with the failure of Parker's The Birth of a Nation, underlines the key problem facing anyone wanting to make a film about slavery. How is it possible to show the brutal, tragic reality of American slavery to a socially diverse mass audience, when many of the issues facing that audience can be traced back to slavery itself?

\section{BIBLIOGRAPHY}

ANDERSON, Reynaldo, D.L. STEPHENSON, and Chante ANDERSON. “'Crowdsourcing' 'The Bad-Ass Slave': A Critique of Quentin Tarantino's Django Unchained." Quentin Tarantino's Django Unchained: The Continuation of Metacinema. Ed. Oliver C. Speck. New York: Bloomsbury, 2014, p. 227-242.

ASPDEN, Peter. “Interview: Steve McQueen on Telling the Truth in Hollywood." Financial Times Magazine, 3 October 2014. Accessed 15 March 2018.

BAKER, Lee D. From Savage to Negro: Anthropology and the Construction of Race, 1896-1954. Berkeley: University of California Press, 1998.

BARNES, Brooks. "Sundance Roars for a Black Film, and Fox Searchlight Bids \$17 Million." New York Times, 26 January 2016. Accessed 15 March 2018.

BEAUCHAMP, Gorman. "The Hagiography of Nat Turner in The Birth of a Nation.” Film \& History, vol. 48, no. 2, 2018, p. 6-10.

BERLIN, Ira. Generations of Captivity: A History of African-American Slaves. Cambridge, MA: Harvard University Press, 2003. 
BERLIN, Ira. Many Thousands Gone: The First Two Centuries of Slavery in North America. Cambridge, MA: Harvard University Press, 1998.

BLIGHT, David W. Beyond the Battlefield: Race, Memory, and the American Civil War. Amherst: University of Massachusetts Press, 2002.

BOWSER, Eileen. The Transformation of Cinema, 1907-1915. New York: Charles Scribner's Sons, 1990.

BRADSHAW, Peter. "The Birth of a Nation Review-Biblical Passion and Cheesy Emotion." The Guardian, 8 December 2016. Accessed 15 March 2018.

BRASHER, Glenn David. “Roots (1977) versus Roots (2016).” Muster, 6 June 2016. Accessed 15 March 2018.

CAMPBELL, Edward D.C., Jr. The Celluloid South: Hollywood and the Southern Myth. Knoxville: University of Tennessee Press, 1981.

CANBY, Vincent. “Drum.” New York Times, 31 July 1976.

CANBY, Vincent. “Mandingo.” New York Times, 8 May 1975.

CARRINGTON, Julian. “12 Years a Slave.” Cinema Scope, no. 57, 2014, p. 74-75.

CHANG, Justin. "Sundance Film Review: The Birth of a Nation." Variety, 25 January 2016. Accessed 15 March 2018.

COLLINS, Gregor. "Joe Walker on the Unflinching Account of 12 Years a Slave." CinemaEditor, vol. 64 , no. 1, 2014, p. 50-52.

CONNELLY, Thomas L., and Barbara L. BELLOWS. God and General Longstreet: The Lost Cause and the Southern Mind. Baton Rouge: Louisiana State University Press, 1982.

CRÉMIEUX, Anne. "La représentation de l'esclavage dans Planet of the Apes et The Brother from Another Planet." Cinéma et histoire/Cinema and History. Eds. Melvyn Stokes and Gilles Menegaldo. Paris: Michel Houdiard, 2008, p. 232-241.

CROMWELL, John W. “The Aftermath of Nat Turner's Insurrection.” The Journal of Negro History, vol. 5, no. 2, 1920, p. 208-234.

CROWTHER, Bosley. "Band of Angels." New York Times, 11 July 1957.

EHRLICH, Evelyn. "The Civil War in Early Film: Origin and Development of a Genre." Southern Quarterly, vol. 19, no. 3, 1981, p. 70-82.

EICHSTEDT, Jennifer L., and Stephen SMALL. Representations of Slavery: Race and Ideology in Southern Plantation Museums. Washington, DC: Smithsonian Institution Press, 2002.

FARNSWORTH, Robert M., ed. Caviar and Cabbage: Selected Columns by Melvin B. Tolson from the Washington Tribune, 1937-1944. Columbia: University of Missouri Press, 1982.

FONER, Eric. “Lincoln's Use of Politics for Noble Ends.” New York Times, 26 November 2012. Accessed 15 March 2018.

FONER, Eric. Reconstruction: America's Unfinished Revolution, 1863-1877. New York: Harper and Row, 1988.

FORD, Lacy K. Deliver Us from Evil: The Slavery Question in the Old South. Oxford: Oxford University Press, 2009.

GARRETT, Daniel. "The Free Mind of a Man in Captivity: 12 Years a Slave, Book and Film." Senses of Cinema, no. 72, 2014. Accessed 15 March 2018. 
GAY, Roxane. "Nate Parker and the Limits of Empathy." New York Times, 19 August 2016. Accessed 15 March 2018.

GRAHAM, Allison. Framing the South: Hollywood, Television, and Race during the Civil Rights Struggle. Baltimore: Johns Hopkins University Press, 2001.

HAMILTON, Holman. Prologue to Conflict: The Crisis and Compromise of 1850. Lexington: University of Kentucky Press, 1964.

HEMBLADE, Christopher. “Amistad.” Empire, no. 105, 1998, p. 34.

HIX, Lisa. "Why Aren't Stories Like 12 Years a Slave Told at Southern Plantation Museums?" Collectors Weekly, 28 February 2014. Accessed 15 March 2018.

HULBERT, Matthew C. “The Birth of a Nation.” Film \& History, vol. 46, no. 2, 2016, p. 108-111.

IRONS, Charles F. The Origins of Proslavery Christianity: White and Black Evangelicals in Colonial and Antebellum Virginia. Chapel Hill: University of North Carolina Press, 2008.

JEFFREY, Julie Roy. “Amistad: Steven Spielberg's ‘True Story.” Historical Journal of Film, Radio and Television, vol. 21, no. 1, 2001, p. 77-96.

KASTER, Gregory L. "Django and Lincoln: The Suffering Slave and the Law of Slavery.” Quentin Tarantino's Django Unchained: The Continuation of Metacinema. Ed. Oliver C. Speck. New York: Bloomsbury, 2014, p. 75-90.

KELLNER, Douglas. "The Horrors of Slavery and Crisis of Humanity in Amistad and 12 Years a Slave." Fotocinema, no. 8, 2014, p. 5-38.

KIRBY, Jack Temple. Media-Made Dixie: The South in the American Imagination. Baton Rouge: Louisiana State University Press, 1978.

"Labor Force Statistics from the Current Population Survey." Bureau of Labor Statistics. Accessed 15 March 2018.

LAFFLY, Tomris. "12 Years a Slave." Film Journal International, vol. 116, no. 11, 2013, p. 132-134.

LAWS, Page. "The Birth of a Nation." Cineaste, 2016, p. 40-42.

MARSH, Calum. “12 Years a Slave.” Sight and Sound, vol. 24, no. 2, 2014. Accessed 15 March 2018.

MAST, Gerald, ed. The Movies in Our Midst: Documents in the Cultural History of Film in America. Chicago: University of Chicago Press, 1982.

MASUR, Kate. "In Spielberg's Lincoln, Passive Black Characters." New York Times, 12 November 2012. Accessed 15 March 2018.

MATHEWS, Donald G. Slavery and Methodism: A Chapter in American Morality, 1780-1845. Princeton: Princeton University Press, 1965.

MORRIS, Nigel. The Cinema of Steven Spielberg: Empire of Light. New York: Columbia University Press, 2007.

NAMA, Adilifu. Race on the QT: Blackness and the Films of Quentin Tarantino. Austin: University of Texas Press, 2015.

NORTHUP, Solomon. Twelve Years a Slave: Narrative of Solomon Northup, a Citizen of New-York, Kidnapped in Washington City in 1841, and Rescued in 1853, from a Cotton Plantation Near the Red River, in Louisiana. Auburn: Derby and Miller, 1853.

OATES, Stephen B. The Fires of Jubilee: Nat Turner's Fierce Rebellion. New York: Harper and Row, 1975. 
POTTER, David M. The Impending Crisis, 1848-1861. Ed. Don E. Fehrenbacher. New York: Harper and Row, 1976.

"Poverty in the United States: Frequently Asked Questions." National Poverty Center. Accessed 15 March 2018.

“Poverty Rate by Race/Ethnicity.” Henry J. Kaiser Family Foundation. Accessed 15 March 2018.

REDIKER, Marcus. The Amistad Rebellion: An Atlantic Odyssey of Slavery and Freedom. New York: Viking, 2012.

RUTENBERG, Jim. “A Dream Undone.” New York Times Magazine, 29 July 2015. Accessed 15 March 2018.

RYAN, Maureen. “TV Review: Roots.” Variety, 24 May 2016. Accessed 26 August 2019.

RYAN, Patrick. “\#OscarsSoWhite Controversy: What You Need to Know.” USA Today, 2 February 2016. Accessed 15 March 2018.

SCOTT, A.O. “Review: In Nate Parker's The Birth of a Nation, Must-See and Won't See Collide." New York Times, 6 October 2016. Accessed 15 March 2018.

SIEGEL, Tatiana, and Rebecca FORD. "My Deal: The Biggest in Sundance History." Hollywood Reporter, 5 February 2016, p. 14.

SMITH, John David, and John C. INSCOE, eds. Ulrich Bonnell Phillips: A Southern Historian and His Critics. Athens: University of Georgia Press, 1993.

SMITH, Nigel M. “Nate Parker: Director with a Back Story.” The Guardian, 21 August 2016. Accessed 15 March 2018.

SNAY, Mitchell. Gospel of Disunion: Religion and Separatism in the Antebellum South. Cambridge: Cambridge University Press, 1993.

SPERLING, Nicole. “The Fall of a Front-Runner.” Entertainment Weekly, 2 September 2016, p. 14-15.

SPERLING, Nicole. "Oscars 2016: Black Film Boom after \#OscarsSoWhite Controversy."

Entertainment Weekly, 12 February 2016, p. 18-19.

STAIGER, Janet. Interpreting Films: Studies in the Historical Reception of American Cinema. Princeton: Princeton University Press, 1992.

STOKES, Melvyn. American History through Hollywood Film: From the Revolution to the 1960s. London: Bloomsbury, 2013.

SWAINE, Jon, Oliver LAUGHLAND, Jamiles LARTEY, and Ciara McCARTHY. "Young Black Men Killed by US Police at Highest Rate in Year of 1,134 Deaths.” The Guardian, 31 December 2015. Accessed 15 March 2018.

TAUBIN, Amy. "Headline Acts." Film Comment, vol. 52, no. 2, 2016, p. 62-64.

TAYLOR, Helen. Scarlett's Women: Gone With the Wind and Its Female Fans. London: Virago, 2014.

TUCKER, William H. The Science and Politics of Racial Research. Urbana: University of Illinois Press, 1994.

Variety Film Reviews. Vol. 1. 1907-1920. New York: R.R. Bowker, 1983.

Variety Film Reviews. Vol. 12. 1968-1970. New York: R.R. Bowker, 1983.

Variety Film Reviews. Vol. 14. 1975-1977. New York: R.R. Bowker, 1983. 
WHITE, Armond. “Can't Trust It." City Arts: New York's Review of Culture, 16 October 2013. Accessed 15 March 2018.

WOOD, Robin. Sexual Politics and Narrative Film: Hollywood and Beyond. New York: Columbia University Press, 1998.

“Young Mr. Lincoln de John Ford." Cahiers du cinéma, no. 223, 1970, p. 29-47.

\section{NOTES}

1. This article is a revised, expanded, and updated version of chapter 2 of Stokes.

2. In this production, Uncle Tom was played by black actor James B. Lowe. In Uncle Tom's Cabin movies before 1914, Uncle Tom had always been played by a white actor in blackface. The first black Uncle Tom had been Sam Lucas in 1914.

3. In both cases, miscegenation was defined in precisely the same way as "sexual relationships between the white and black races" (quoted in Mast 213, 333).

4. African American movie critic Melvin B. Tolson argued that it was more dangerous to the black community than The Birth of a Nation: "The Birth of a Nation was such a barefaced lie that a moron could see through it. Gone with the Wind is such a subtle lie that it will be swallowed as the truth by millions of blacks and whites alike" (quoted in Farnsworth 214).

5. The break-up of slave families is echoed in Gone with the Wind in the sequence in which Scarlett arrives home at Tara near the end of the war to find that only the "house servants"-Mammie, Pork, and Prissy-remain. All the other slaves have gone. And although they may, like Big Sam and the other field hands, have been conscripted by the Confederacy, the situation at Tara did faithfully reflect the social realities of 1864-65 when, as Eric Foner observes, "it seemed that half the South's black population took to the roads" (Foner, 1988 80). A high proportion of slaves did leave their former plantations to travel and move around, either because freedom to them meant their right to escape both their former workplace and the pass system that existed under slavery or because they were in search of family members and friends (Foner, 1988 80-84).

6. Edward Campbell notes the breakdown of the American cinema audience after 1965 into white suburban movie-goers and black inner-city spectators. Blaxploitation films were aimed at the latter (Campbell 175).

7. Other films with Middle Passage sequences include D.W. Griffith's Abraham Lincoln (1930) and Slaves, as well as the television series Roots.

8. The returns from the US only $(\$ 44,175,000)$ barely covered the production costs. All figures from IMDb.

9. Still a privately owned sugar cane plantation, the Evergreen Plantation is also open six days a week for "plantation tours." For analyses of how plantation museums in the South tend to sideline the history of slavery, see Eichstedt and Small, and Hix.

10. Solomon Northup himself argued on very similar lines. "It is not the fault of the slaveholder that he is cruel," he wrote in his original book, "so much as it is the fault of the system under which he lives. He cannot withstand the influence of habit and associations that surround him" (Northup 206).

11. "This film isn't just an Afro-American film," declared Joe Walker, editor of 12 Years a Slave. "It's universal. Slavery exists now all around the world [...] in the Middle East, in India, Saudi Arabia. Sadly, it's an eternal story" (quoted in Collins 50). The DVD of the film released in the UK contained a leaflet with a message from director Steve McQueen, as patron of Antislavery International, asking readers to join the organization.

12. Fox Searchlight was also responsible for the 2016 best picture winner, Birdman. 
13. Page Laws points out that both Turner's Confessions and the recollections of Solomon Northup were “'told to' a white amanuensis" (Laws 42).

14. In Parker's film, Turner has both a wife and a child, unlike the real-life Nat Turner.

15. Gorman Beauchamp comments that "the proportion of women and children in this list presents a troubling portrait of the revolt, which, although morally grounded in the actual villainy of slave practices, would disturb any devoted hagiographer" (Beauchamp 7).

\section{ABSTRACTS}

This article analyses the representation of American slavery in film over more than a century. It argues that the filmic construction of slavery has always been controversial. As American cinema evolved, the dominant filmic view of slavery presented it as a benign institution. Yet, it is noted, even in films such as The Birth of a Nation (1915) and Gone with the Wind (1939), there were sequences that challenged this interpretation and hinted at the brutality and exploitation of the institution. In the aftermath of World War II, a more critical view of slavery began to emerge on film. Yet slavery itself was not a popular theme with audiences, as demonstrated by the reception of Amistad (1997). This seemed to change in the second decade of the twenty-first century when three films-Lincoln (2012), Django Unchained (2012), and 12 Years a Slave (2013)-dealt critically with slavery while also attracting a mass audience. The reasons for the success of these filmsand the failure of The Birth of a Nation (2016)-are discussed in relation to broader changes in American social and cultural attitudes.

Cet article analyse la représentation de l'esclavage nord-américain au cinéma sur plus d'un siècle. On y montre que la construction cinématographique de l'esclavage a toujours été sujette à controverse. Pendant longtemps, les réalisateurs américains ont minimisé la violence de l'esclavage. Pourtant, des films tels que Naissance d'une nation (1915) et Autant en emporte le vent (1939) contiennent aussi des séquences où cette violence est suggérée. Après la Seconde Guerre mondiale, le cinéma a développé un regard plus critique sur l'esclavage, sans toutefois que le thème ne devienne populaire auprès du public, comme le montre la réception d'Amistad (1997). La situation a évolué depuis : trois films sont sortis coup sur coup dans les années 2010 - Lincoln (2012), Django Unchained (2012) et 12 Years a Slave (2013) - qui présentent le système esclavagiste sous un jour beaucoup plus sombre tout en ayant connu un succès critique et commercial. Cet article évoque les raisons de ce succès - et celles de l'échec de The Birth of a Nation (2016) - en les reliant à des changements de fond dans la société et la culture nord-américaines.

\section{INDEX}

Mots-clés: cinéma, esclavage, questions raciales, représentation, public

Keywords: cinema, slavery, race, representation, audience 
AUTHOR

MELVYN STOKES

University College London 